\title{
What is new in the 2018 ESC guidelines for the management of cardiovascular diseases during pregnancy?
}

Irene M. Lang (D)

Received: 18 June 2019 / Accepted: 28 June 2019 / Published online: 23 September 2019

(C) The Author(s) 2019

\begin{abstract}
Summary of key elements of the new 2018 European Society of Cardiology (ESC) guidelines for the management of cardiovascular diseases during pregnancy Cardiovascular diseases during pregnancy are the most common causes of pregnancy-associated mortality.

Vaginal delivery is the preferred mode of birth in the majority of pregnancies.

It is recommended that patients with modified World Health Organization (mWHO) class IV risk are counselled against pregnancy.

Patients carrying mWHO II-III, III, and class IV risks should undergo prepregnancy counselling by a multidisciplinary pregnancy heart team to determine a delivery plan and define postpartum care.

Specific medications should not be principally withheld in pregnancy but the risk-benefit ratio should be carefully evaluated prior to administration.

Beta blockers are recommended during and after pregnancy for congenital long QT syndrome and catecholaminergic polymorphic ventricular tachycardia. Low molecular weight heparin is the ideal substance for prophylaxis and treatment of venous thromboembolism in pregnancy under weekly monitoring of antifactor Xa activity.
\end{abstract}

Keywords Pregnancy heart team - Aortic disease · Cardiomyopathy · Pulmonary hypertension · Risk stratification
I. M. Lang, MD $(\bowtie)$

Department of Internal Medicine II, Division of Cardiology,

Medical University of Vienna, Währinger Gürtel

18-20, 1090 Vienna, Austria

irene.lang@meduniwien.ac.at
The 2018 European Society of Cardiology (ESC) guidelines for the management of cardiovascular diseases during pregnancy have recently been published in the European Heart Journal [1]. These guidelines were prepared by a multidisciplinary group of experts. Guidelines are intended to provide guidance in physicians' decision making by a summary of all available evidence at the time of the writing process, including new concepts and treatments as per evidence and experience and by defining standards of organization of care. For example, staffing requirements for the new interdisciplinary pregnancy heart team are provided, conditions are defined where counselling is required, an optimal care setting is defined and minimum follow-up visits during pregnancy including recommended logistics for delivery in relation to calculable risk are described.

The present article presents a brief and condensed summary of new and practically relevant items contained in the 2018 ESC guidelines for the management of cardiovascular diseases during pregnancy [1], highlighting what is new since the last edition of the guidelines in 2011.

\section{General introduction}

Pregnancy is a physiological condition that mimics disease. Therefore, the clinical diagnosis of common conditions that are associated with fluid retention, such as cardiorenal syndromes, may require diagnostic practices that divert from accepted standards of operations. For example, diagnosing heart failure may be more difficult because the physiological changes that occur during pregnancy may mimic cardiovascular disease, and thus mask an underlying disease condition. It is therefore necessary to take the condition of pregnancy into account, to perform in-depth analysis of the medical history, particularly the history of 
preceding pregnancies, and histories or family histories of hypertension or pre-eclampsia, and to perform a physical examination bearing in mind more subtle signs of disease. Dyspnea that is out of proportion to the pregnancy condition or a new heart murmur necessitate immediate transthoracic echocardiography. It is important to measure blood pressure in a standardized fashion, to search for proteinuria, and repeat those examinations throughout pregnancy.

\section{The mWHO classification of maternal risk}

It is recommended to perform risk assessment in all women of childbearing age with cardiac diseases and before conception, using the mWHO classification of maternal risk in pregnancy [2] (class of recommendation I, evidence level C), (see Table 1). Risk estimation should be further refined by taking into account predictors that have been identified in studies that included large populations of pregnant women with various diseases, such as the cardiac disease in pregnancy (CARPREG) study [3], the ZAHARA study [4, 5] and the registry of pregnancy and cardiac disease (ROPAC) [6]. Fertility treatment is contraindicated in women with mWHO class IV. Fertility treatment requires a careful risk-benefit ratio assessment in women with mWHO class III disease, and in women who need anticoagulation.

\section{The pregnancy heart team}

The pregnancy heart team has been put forward in the new guidelines and evolved from the multidisciplinary management team of the 2011 guidelines. The pregnancy heart team focuses on women with a moderate or high risk of complications during pregnancy (mWHO II-III, III and IV), providing prepregnancy counselling and management during pregnancy and around delivery at an expert center. The minimum team requirements are a cardiologist, an obstetrician and an anesthetist, all with sufficient expertise in the management of high-risk pregnancies in women with cardiovascular diseases. Pregnant women with artificial heart valves should be cared for by the pregnancy heart team.

\section{Treatment of hypertension}

Pregnant women with moderate to high risk for preeclampsia should start with 100-150 mg Aspirin per day at the beginning of week 12 and continue this medication until weeks 36-37.

All pregnant women with sustained elevation of blood pressure $\geq 150 / 95 \mathrm{~mm} \mathrm{Hg}$ should receive antihypertensive treatment.

Pregnant women with sustained elevation of blood pressure $>140 / 90 \mathrm{mmHg}$ should receive antihypertensive treatment in the presence of: pre-eclampsia, known arterial hypertension, arterial hypertension with diagnosed organ damage.

Methyldopa, labetalol, and calcium antagonists are recommended to treat arterial hypertension in pregnancy.

\section{Assisted reproductive therapy}

Despite meeting patient wishes and expectations for reproduction in difficult settings, assisted reproduction entails additional risks on top of the underlying risk of pregnancy. For example, superovulation because of ovarian hyperstimulation (OHSS) leads to significant fluid shifts and an increased risk of thrombosis [7]. The risk of OHSS can be reduced by use of lowdose follicle-stimulating hormone (FSH) in combination with a gonadotropin-releasing hormone (GnRH) antagonist, and careful monitoring. Single embryo transfer is the preferred technique in women with heart disease because it is known that twin pregnancies are associated with significantly more complications than singleton pregnancies [8].

\section{Use of bromocriptine in peripartum cardiomyopathy (PPCM)}

The EURObservational Research Programme international PPCM registry has provided important new information on PPCM [9]. Key predisposing factors include multiparity, African ethnicity, smoking, diabetes, pre-eclampsia, malnutrition, advanced age and teenage pregnancy. The cause of PPCM is uncertain but potential etiologies include inflammation and vascular damage. The biologically active $16-\mathrm{kDa}$ prolactin and other factors, such as soluble fms-like tyrosine kinase 1 (sFlt1), may initiate and drive PPCM [10]. Based on these insights, bromocriptine $(2.5 \mathrm{mg}$ once daily) for at least 1 week may be considered in uncomplicated cases, whereas prolonged treatment ( $2.5 \mathrm{mg}$ twice daily for 2 weeks, then $2.5 \mathrm{mg}$ once daily for 6 weeks) may be considered in patients with ejection fraction (EF) $<25 \%$ and/or cardiogenic shock. Bromocriptine treatment should be accompanied by anticoagulation with heparin, low molecular weight heparin (LMWH) or unfractionated heparin, at least in prophylactic dosages. Essential steps of treatment for patients with acute PPCM have been summarized as bromocriptine, oral heart failure therapies, anticoagulants, vasorelaxing agents, and diuretics (BOARD) [11].

\section{Advice on contraception and the termination of pregnancy in women with cardiac diseases}

Women with a moderate or high risk of complications during pregnancy (mWHO II-III, III and IV) should be advised for a particular type of contraception with respect to the risk of pregnancy according to the mWHO classification (see above), which is able to estimate the 
Table 1 Modified World Health Organization ( $\mathrm{mWHO}$ ) classification of maternal cardiovascular risk (mod. from [1])

\begin{tabular}{|c|c|c|c|c|c|}
\hline & mWHO 1 & mWHO II & mWHO II-III & mWHO III & mWHO IV \\
\hline \multirow{14}{*}{$\begin{array}{l}\text { Diagnosis } \\
\text { (if } \\
\text { otherwise } \\
\text { well and } \\
\text { uncompli- } \\
\text { cated) }\end{array}$} & \multirow{2}{*}{$\begin{array}{l}\text { Small or mild } \\
\text { - pulmonary stenosis } \\
\text { - patent ductus } \\
\text { arteriosus } \\
\text { - mitral valve prolapse }\end{array}$} & \multirow{2}{*}{$\begin{array}{l}\text { Unoperated atrial } \\
\text { or ventricular } \\
\text { septal defect }\end{array}$} & $\begin{array}{l}\text { Mild left ventricular } \\
\text { impairment ( } \mathrm{EF}>45 \%)\end{array}$ & $\begin{array}{l}\text { Moderate left ventricular impairment } \\
\text { (EF 30-50\%) }\end{array}$ & $\begin{array}{l}\text { Pulmonary arterial hyperten- } \\
\text { sion }\end{array}$ \\
\hline & & & $\begin{array}{l}\text { Hypertrophic cardiomy- } \\
\text { opathy }\end{array}$ & $\begin{array}{l}\text { Previous peripartum cardiomyopathy } \\
\text { without any residual left ventricular } \\
\text { impairment }\end{array}$ & \multirow{2}{*}{$\begin{array}{l}\text { Previous peripartum } \\
\text { cardiomyopathy with any } \\
\text { residual left ventricular } \\
\text { impairment }\end{array}$} \\
\hline & $\begin{array}{l}\text { Successfully repaired } \\
\text { simple lesions (atrial } \\
\text { or ventricular septal } \\
\text { defect, patent ductus } \\
\text { arteriosus, anomalous } \\
\text { pulmonary venous } \\
\text { drainage) }\end{array}$ & $\begin{array}{l}\text { Repaired tetral- } \\
\text { ogy of Fallot }\end{array}$ & $\begin{array}{l}\text { Native or tissue valve } \\
\text { disease not considered } \\
\text { WHO I or IV (mild mitral } \\
\text { stenosis, moderate } \\
\text { aortic stenosis) }\end{array}$ & Mechanical valve & \\
\hline & \multirow[t]{11}{*}{$\begin{array}{l}\text { Atrial or ventricular } \\
\text { ectopic beats, isolated }\end{array}$} & $\begin{array}{l}\text { Most arrhythmias } \\
\text { (supraventricular } \\
\text { arrhythmias) }\end{array}$ & $\begin{array}{l}\text { Marfan or other HTAD } \\
\text { syndrome without aortic } \\
\text { dilatation }\end{array}$ & $\begin{array}{l}\text { Systemic right ventricle with good or } \\
\text { mildly decreased ventricular function }\end{array}$ & $\begin{array}{l}\text { Severe systemic ventricular } \\
\text { dysfunction (EF }<30 \% \text { or NYHA } \\
\text { classes III-IV) }\end{array}$ \\
\hline & & \multirow[t]{10}{*}{$\begin{array}{l}\text { Turner syndrome } \\
\text { without aortic } \\
\text { dilatation }\end{array}$} & \multirow[t]{4}{*}{$\begin{array}{l}\text { Aorta }<45 \mathrm{~mm} \text { in } \\
\text { bicuspid aortic valve } \\
\text { pathology }\end{array}$} & \multirow[t]{4}{*}{ Fontan circulation } & $\begin{array}{l}\text { A patient with Fontan circula- } \\
\text { tion experiencing any medical } \\
\text { complication }\end{array}$ \\
\hline & & & & & Severe mitral stenosis \\
\hline & & & & & $\begin{array}{l}\text { Severe symptomatic aortic } \\
\text { stenosis }\end{array}$ \\
\hline & & & & & \multirow{3}{*}{$\begin{array}{l}\text { Systemic right ventricle with } \\
\text { moderate or severely } \\
\text { decreased ventricular function }\end{array}$} \\
\hline & & & Repaired coarctation & Unrepaired cyanotic heart disease & \\
\hline & & & \multirow[t]{5}{*}{$\begin{array}{l}\text { Atrioventricular septal } \\
\text { defect }\end{array}$} & & \\
\hline & & & & $\begin{array}{l}\text { Moderate mitral stenosis } \\
\text { Severe asymptomatic aortic stenosis } \\
\text { Moderate aortic dilatation }(40-45 \mathrm{~mm}\end{array}$ & $\begin{array}{l}\text { Severe aortic dilatation } \\
\text { ( }>45 \mathrm{~mm} \text { in Marfan syndrome } \\
\text { or other HTAD, }>50 \mathrm{~mm} \text { in } \\
\text { bicuspid aortic valve. Turner } \\
\text { syndrome ASI }>25 \mathrm{~mm} / \mathrm{m}^{2} \text {, } \\
\text { tetralogy of Fallot }>50 \mathrm{~mm} \text { ) }\end{array}$ \\
\hline & & & & \multirow{2}{*}{$\begin{array}{l}\text { Moderate aortic dilatation ( } 40-45 \mathrm{~mm} \\
\text { in Marfan syndrome or other HTAD; } \\
45-50 \mathrm{~mm} \text { in bicuspid aortic valve. } \\
\text { Turner syndrome ASI } 20-25 \mathrm{~mm} / \mathrm{m}^{2} \text {, } \\
\text { tetralogy of Fallot }<50 \mathrm{~mm} \text { ) }\end{array}$} & $\begin{array}{l}\text { Vascular Ehlers-Danlos syn- } \\
\text { drome }\end{array}$ \\
\hline & & & & & \multirow[t]{2}{*}{ Severe (re)coarctation } \\
\hline & & & & Ventricular tachycardia & \\
\hline
\end{tabular}

risk with each method for a given medical condition. Advice is best provided by cardiologists with appropriate training or obstetricians and should be given at the time of menarche. An important rule is that unplanned pregnancy is particularly risky and has to be avoided. In the UK up to $30 \%$ of the first sexual intercourse occur before the age of 15 years [12] regardless of the presence of heart disease [13]. The key issues for a given contraceptive method are reliability and potential for complications, with thrombosis and infections being the most important; however, there are also advantages of hormonal contraception, such as control of menstruation, prevention of anemia, reduction of dysmenorrhea and prevention of hyperandrogenism.

\section{Further innovative contents of the new guidelines}

Specific levels of surveillance for arrhythmia are provided with respect to the risk level for hemodynamic compromise at delivery.
New information on pharmacokinetics in pregnancy is given, including more detailed information on pharmacodynamics in animal experiments on all drugs.

The U.S. Food \& Drug Administration (FDA) categories A-X as used for all drugs in 2011 have been replaced by descriptive risk summaries and preclinical safety data, including those for new drugs.

\section{Novel messages of the new 2018 ESC guidelines for the management of cardiovascular diseases during pregnancy}

- The use of the mWHO classification of maternal risk is recommended.

- The pregnancy heart team is introduced.

- Assisted reproductive therapy is defined.

- Bromocriptine is recommended for the treatment for peripartum cardiomyopathy (PPCM).

- Advice is given on contraception and the termination of pregnancy in women with cardiac diseases. 
Funding Open access funding provided by Austrian Science Fund (FWF).

Conflict of interest I.M. Lang declares that she has no competing interests.

Open Access This article is distributed under the terms of the Creative Commons Attribution 4.0 International License (http://creativecommons.org/licenses/by/4.0/), which permits unrestricted use, distribution, and reproduction in any medium, provided you give appropriate credit to the original author(s) and the source, provide a link to the Creative Commons license, and indicate if changes were made.

\section{References}

1. Regitz-Zagrosek V, Roos-HesselinkJW, Bauersachs J, Blomstrom-Lundqvist C, Cifkova R, De Bonis M, Iung B, Johnson MR, Kintscher U, Kranke P, Lang IM, Morais J, Pieper PG, Presbitero P, Price S, Rosano GMC, Seeland U, Simoncini T, Swan L, Warnes CA. ESC Guidelines for the management of cardiovascular diseases during pregnancy. Eur Heart J. 2018;2018(39):3165-241.

2. Pijuan-Domenech A, Galian L, Goya M, Casellas M, Merced C, Ferreira-Gonzalez I, Marsal-Mora JR, DosSubira L, Subirana-Domenech MT, Pedrosa V, Baro-Marine F, Manrique S, Casaldaliga-Ferrer J, Tornos P, Cabero L, Garcia-Dorado D. Cardiac complications during pregnancy are better predicted with the modified WHO risk score. Int J Cardiol. 2015;195:149-54.

3. Silversides CK, Grewal J, Mason J, Sermer M, Kiess M, RychelV, WaldRM, ColmanJM,SiuSC.Pregnancy outcomes in women with heart disease: The CARPREG II Study. J Am Coll Cardiol. 2018;71:2419-30.

4. Siu SC, Sermer M, Harrison DA, Grigoriadis E, Liu G, Sorensen S, Smallhorn JF, Farine D, Amankwah KS, Spears JC, Colman JM. Risk and predictors for pregnancy-related complications in women with heart disease. Circulation. 1997;96:2789-94.

5. Drenthen W, Boersma E, Balci A, Moons P, Roos-Hesselink JW, Mulder BJ, Vliegen HW, van Dijk AP, Voors AA, Yap SC, van Veldhuisen DJ, Pieper PG. Predictors of pregnancy complications in women with congenital heart disease. Eur Heart J. 2010;31:2124-32.

6. RuysTP, Roos-HesselinkJW,HallR, Subirana-DomenechMT, Grando-Ting J, Estensen M, Crepaz R, Fesslova V, Gurvitz M, De Backer J, Johnson MR, Pieper PG. Heart failure in pregnant women with cardiac disease: data from the ROPAC. Heart. 2014;100:231-8.
7. Konstantinides SV, Torbicki A, Agnelli G, Danchin N, Fitzmaurice D, Galie N, Gibbs JS, Huisman MV, Humbert M, Kucher N, Lang I, Lankeit M, Lekakis J, Maack C, Mayer E, Meneveau N, Perrier A, Pruszczyk P, Rasmussen LH, Schindler TH, Svitil P, Vonk Noordegraaf A, Zamorano JL, Zompatori M. ESC guidelines on the diagnosis and management of acute pulmonary embolism. Eur Heart J. 2014;35(43):3033-69. https://doi.org/10.1093/eurheartj/ ehu283.3069a-3069k.

8. Ombelet W, Martens G, De Sutter P, Gerris J, Bosmans E, Ruyssinck G, Defoort P, Molenberghs G, Gyselaers W. Perinatal outcome of 12,021 singleton and 3108 twin births after non-IVF-assisted reproduction: a cohort study. Hum Reprod. 2006;21:1025-32.

9. Sliwa K, Mebazaa A, Hilfiker-Kleiner D, Petrie MC, Maggioni AP, Laroche C, Regitz-Zagrosek V, Schaufelberger M, Tavazzi L, van der Meer P, Roos-Hesselink JW, Seferovic P, van Spandonck-Zwarts K, Mbakwem A, Bohm M, Mouquet F, Pieske B, Hall R, Ponikowski P, Bauersachs J. Clinical characteristics of patients from the worldwide registry on peripartum cardiomyopathy (PPCM): EURObservational Research Programme in conjunction with the Heart Failure Association of the European Society of Cardiology Study Group on PPCM. EurJ HeartFail. 2017;19:1131-41.

10. Patten IS, Rana S, Shahul S, Rowe GC, Jang C, Liu L, Hacker MR, RheeJS, MitchellJ, Mahmood F, Hess P, Farrell C, Koulisis N, Khankin EV, Burke SD, Tudorache I, Bauersachs J, del Monte F, Hilfiker-Kleiner D, Karumanchi SA, AranyZ. Cardiac angiogenicimbalanceleads to peripartum cardiomyopathy. Nature. 2012;485:333-8.

11. Arrigo M, Blet A, Mebazaa A. Bromocriptine for the treatment of peripartum cardiomyopathy: welcome on BOARD. Eur HeartJ. 2017;38:2680-2.

12. Mercer $\mathrm{CH}$, Tanton C, Prah P, Erens B, Sonnenberg P, Clifton S, Macdowall W, Lewis R, Field N, Datta J, Copas AJ, Phelps A, Wellings K, Johnson AM. Changes in sexual attitudes and lifestyles in Britain through the life course and over time: findings from the National Surveys of Sexual Attitudes and Lifestyles (Natsal). Lancet. 2013;382:1781-94.

13. Vigl M, Kaemmerer M, Niggemeyer E, Nagdyman N, SeifertKlauss V, Trigas V, Bauer U, Schneider KT, Berger F, Hess J, Kaemmerer H. Sexuality and reproductive health in women with congenital heart disease. Am J Cardiol. 2010;105:538-41.

Publisher's Note Springer Nature remains neutral with regard to jurisdictional claims in published maps and institutional affiliations. 